\title{
PENGEMBANGAN LEMBAR KERJA PESERTA DIDIK BERBASIS LINGKUNGAN UNTUK MENINGKATKAN MOTIVASI DAN HASIL BELAJAR PADA MATERI PEMISAHAN CAMPURAN DAN ANALISIS DI SMK NEGERI 3 KABUPATEN BANTAENG
}

\author{
Akhmad $^{1}$, Muhammad Danial' ${ }^{2}$, Muris $^{3}$ \\ ${ }^{1}$ Guru SMK Negeri 3 Bantaeng \\ ${ }^{2,3}$ Dosen Program Pascasarjana Universitas Negeri Makassar \\ Email:akhmad@yahoo.com
}

\begin{abstract}
ABSTRAK
Penelitian ini adalah penelitian pengembangan (research and development) yang meliputi pengembangan perangkat pembelajaran yang dikhususkan pada pengembangan lembar kerja peserta didik (LKPD) untuk materi pemisahan dan analisis pada Peserta didik kelas XII SMK Negeri 3 Bantaeng Kabupaten Bantaeng. Prosedur pengembangan yang digunakan dalam penelitian ini adalah Model Thiagarajan yang terdiri atas 4 tahap yaitu define, design, develop dan disseminate atau diadaptasikan menjadi Model 4-D yaitu pendefinisian, perancangan, pengembangan dan penyebaran. LKPD berbasis lingkungan yang dikembangkan, telah divalidasi oleh pakar dan praktisi serta telah mengalami revisi kecil sehingga didapatkan hasil yang layak digunakan. Hasil penelitian menunjukkan bahwa perangkat pembelajaran kooperatif tipe STAD bersifat valid, praktis dan efektif. Lembar kerja peserta didik (LKPD) yang digunakan telah memenuhi kriteria kevalidan yaitu kategori "sangat valid". Perangkat pembelajaran lain yang divalidasi sebagai data pendukung meliputi buku peserta didik (BPD), dan rencana pelaksanaan pembelajaran (RPP) berada pada kategori "Valid". LKPD yang digunakan dinyatakan praktis karena keterlaksanaan LKPD berada pada kategori terlaksana seluruhnya dan respon guru memberikan respon positif. LKPD dikatakan efektif karena telah memenuhi kriteria keefektifan, dengan hasil : (1) Guru mampu mengelola proses pembelajaran dengan kategori sangat tinggi; (2) Peserta didik menjadi lebih aktif dalam proses pembelajaran, yang terlihat bahwa semua kategori pada aktivitas peserta didik terpenuhi; (3) Aktivitas guru pada semua kategori terpenuhi; (4) Tes hasil belajar seluruh peserta didik memiliki rata-rata 81.47 dari skor 100 dengan peserta didik yang tuntas belajar 22 orang atau 88\%; (5) Pada umumnya peserta didik termotivasi setelah mengikuti pembelajaran dalam kategori baik; (6) Peserta didik memberikan respon positif terhadap LKPD yang digunakan.
\end{abstract}

Kata kunci: LKPD Berbasis Lingkungan, Motivasi dan Hasil Belajar.

\begin{abstract}
This research is the development of (research and development), which includes the development of learning tools that is devoted to the development of learners' worksheets (LKPD) for material separation and analysis on Learners class XII SMK Negeri 3 Bantaeng Bantaeng. Development procedures used in this study is a model Thiagarajan consisting of four stages: define, design, develop and disseminate or adapted into a 4-D model is the definition, design, development and deployment. LKPD based environments are developed, validated by experts and practitioners and has undergone minor revisions to obtain decent results used. The results showed that the device STAD cooperative learning are valid, practical and effective. Worksheet learners (LKPD) used met the criteria of validity, namely the category of "very valid". Additional learning tools are validated as supporting data, including books learners (BPD), and the lesson plan (RPP) is in the category "Valid". LKPD
\end{abstract}


used otherwise practical for LKPD implemented entirely in the category and the response of teachers gave a positive response. LKPD said to be effective because it has met the criteria of effectiveness, with the results: (1) The teacher is able to manage the learning process with a very high category; (2) The students become more active in the learning process, it seemed that all the categories on the activity of learners are met; (3) Activities teachers in all categories are met; (4) The test results of all students study had an average score of 81.47 out of 100 with learners who pass the study 22 people or $88 \%$; (5) In general, learners are motivated after attending a lesson in both categories; (6) The students responded positively to LKPD used.

Keywords: Based LKPD Environment, Motivation and Learning Outcomes.

\section{PENDAHULUAN}

Dalam pembelajaran kimia sangat memerlukan kegiatan penunjang berupa praktikum maupun eksperimen di laboratorium. Hal ini dikarenakan metode praktikum adalah salah satu bentuk pendekatan keterampilan proses. Bagi peserta didik diadakannya praktikum selain dapat melatih bagaimana penggunaan alat dan bahan yang tepat, juga membantu pemahaman mereka terhadap materi kimia yang diajarkan di kelas. Selain itu, bagi peserta didik yang memiliki rasa ingin tahu tinggi, maka melalui praktikum mereka dapat memperoleh jawaban dari rasa ingin tahunya secara nyata.

Namun demikian tidak semua sekolah memiliki laboratorium yang memadai, sehingga tidak semua konsep kimia yang diajarkan diikuti praktikum di laboratorium. Untuk melaksanakan praktikum yang berkaitan dengan materi pokok yang diajarkan di kelas diperlukan seperangkat alat dan bahan yang kadang-kadang sulit dipenuhi oleh sekolah. Ketiadaan alat dan bahan kimia sering menjadi kendala tidak dilakukannya praktikum, meskipun guru pengampu memiliki petunjuk praktikumnya. Oleh karena itu sangat diperlukan kreativitas guru kimia dalam mencari alternatif bahan dan alat lain yang dapat digunakan agar praktikum tetap dapat dilaksanakan. Dengan demikian pelaksanaan praktikum tidak bergantung pada fasilitas laboratorium yang ada di sekolah, tetapi cukup menggunakan bahan dan alat yang dengan mudah dijumpai dalam kehidupan sehari-hari.
Bahan ajar dan laboratorium merupakan sarana penunjang keberhasilan proses belajar mengajar. Bahan ajar yang dapat digunakan dalam proses pembelajaran terdapat berbagai macam. LKPD (Lembar Kerja Peserta didik) merupakan salah satu jenis bahan ajar cetak yang sering digunakan oleh guru dalam proses pembelajaran. LKPD tersebut biasanya bukan merupakan buatan guru sendiri, melainkan menggunakan LKPD yang beredar di pasaran. LKPD tersebut terdapat diantaranya tidak sesuai dengan kurikulum yang sedang digunakan.

Data yang diperoleh dari observasi lapangan, diketahui bahwa LKPD yang digunakan oleh guru bukan merupakan LKPD yang disusun sendiri melainkan LKPD yang dikumpulkan dari sejumlah buku bahan ajar yang tersedia di sekolah. Beberapa LKPD yang digunakan, diketahui isinya tidak sesuai silabus, SK-KD yang digunakan dengan kurikulum yang berlaku saat ini. Ketidaksesuaian juga terjadi pada struktur penulisan, materi yang disajikan terlalu berbelit-belit sehingga melenceng dengan pencapaian kompetensi belajar peserta didik, alat dan bahan yang digunakan lebih banyak tidak sesuai dengan kondisi yang ada di sekolah. Seorang guru harus memperhatikan hal tersebut sebelum memutuskan untuk menggunakan LKPD itu. Penggunaan LKPD seperti ini hanya membuat peserta didik tidak mandiri dalam belajar dan peserta didik cenderung menjadi malas untuk belajar dari sumber buku yang lain, sebab dalam setiap proses 
pembelajaran, guru hanya bergantung pada LKPD.

Peserta didik diberikan LKPD pada proses pembelajaran sering tidak diikuti dengan penjelasan materi yang ada dalam LKPD dan juga tugas serta latihan yang dikerjakan oleh peserta didik dilakukan tanpa bimbingan dari guru, sebab guru lebih sering tidak berada di kelas mendampingi peserta didik saat mengerjakan LKPD. Banyak peserta didik yang tidak mau mengerjakan secara mandiri dan lebih cenderung melihat pekerjaan temannya. Peserta didik tidak mengerti terhadap materi yang diajarkan dan hasil belajarnya menjadi kurang maksimal merupakan dampak dari hal tersebut. LKPD yang ada, hanya digunakan sebagai syarat untuk melengkapi nilai, dan tidak ada tindak lanjut dalam pengerjaan LKPD atau pembahasan dari guru terhadap tugas dan latihan-latihan yang ada dalam LKPD.

Lembar kerja peserta didik yang beredar juga kurang memberikan pengalaman pada peserta didik khususnya pada mata pelajaran kimia di SMK. Oleh sebab itu dikembangkan suatu LKPD yang bertujuan agar peserta didik dapat lebih mudah memahami konsep pemisahan dan analisis melalui LKPD hasil pengembangan. Penanaman konsep secara mantap diperlukan pembelajaran yang menekankan pada pemberian pengalaman langsung yaitu dengan metode pengamatan langsung atau praktikum. Oleh sebab itu akan dikembangkan LKPD berpendekatan lingkungan. LKPD berpendekatan lingkungan ini merupakan LKPD yang dikembangkan untuk memberikan pemahaman konsep kimia dengan cara melakukan pengamatan dengan memanfaatkan lingkungan sebagai sumber belajar.

Lembar kerja peserta didik berbasis lingkungan yang memanfaatkan lingkungan sebagai sumber belajar ini, harapannya dapat meningkatkan pemahaman konsep peserta didik terhadap materi pemisahan dan analisis. Peserta didik akan belajar lebih mandiri ketika mengerjakan soal-soal yang terdapat dalam LKPD, hal ini akan berpengaruh terhadap hasil belajar peserta didik. Dalam penelitian ini, LKPD Berbasis Lingkungan akan diterapkan di SMK Negeri 3 Bantaeng. Berdasarkan kenyataan di lapangan, sebagian besar guru kimia relatif hanya sedikit melakukan kegiatan praktikum, yaitu hanya bergantung pada alat dan bahan yang tersedia. Padahal praktikum merupakan kegiatan wajib yang harusnya menyertai setiap pembelajaran materi di kelas. Berkaitan dengan hal itu, maka penting bagi guru kimia untuk dibekali pengetahuan mengenai bagaimana cara mengembangkan lembar kerja peserta didik (LKPD) yang berbasis lingkungan, sehingga kendala fasilitas laboratorium yang tidak memadai dapat diatasi dengan baik. Pada kesempatan ini akan disajikan beberapa contoh praktikum kimia sederhana dengan menggunakan alat dan bahan yang ada di lingkungan sekitar.

Berdasarkan latar belakang masalah yang telah diuraikan di atas, maka rumusan masalah dalam penelitian ini adalah: (1) Bagaimana proses pengembangan lembar kerja peserta didik berbasis lingkungan pada materi pokok pemisahan dan analisis untuk kelas XII SMK ? (2) Seberapa besar tingkat kevalidan, kepraktisan dan keefektifan lembar kerja peserta didik untuk meningkatan motivasi dan hasil belajar kimia pada materi pokok pemisahan dan analisis untuk kelas XII SMK ?

Berdasarkan rumusan masalah di atas, maka tujuan dari penelitian ini adalah: (1) Untuk memperoleh lembar kerja peserta didik berbasis lingkungan pada materi pokok pemisahan dan analisis untuk kelas XII SMK yang valid, praktis dan efektif. (2) Untuk mengetahui tingkat kevalidan, kepraktisan dan keefektifan lembar kerja peserta didik dalam meningkatan motivasi dan hasil belajar kimia pada materi pemisahan dan analisis untuk kelas XII SMK.

\section{METODE PENELITIAN}

Jenis penelitian ini digolongkan ke dalam penelitian pengembangan (research 
and development) yang meliputi pengembangan perangkat pembelajaran yang dikhususkan pada pengembangan lembar kerja peserta didik (LKPD) yang diterapkan dalam model pembelajaran kooperatif tipe STAD (Student Team Achievement Division).

Penelitian ini dilaksanakan di SMK Negeri 3 Bantaeng dan subjek penelitiannya adalah peserta didik kelas XII dipilih kelas XII Keperawatan A dari 10 kelas XII paralel yang ada dengan jumlah peserta didik 25 orang terdiri dari 2 laki-laki dan 23 perempuan pada semester genap tahun pelajaran 2015/2016. Penentuan subjek penelitian ini dilakukan secara random sampling.

Model pengembangan perangkat pembelajaran yang digunakan dalam penelitian ini merujuk pada model pengembangan Thiagarajan, Semmel \& Semmel (1974) dalam Trianto (2010: 189) adalah model 4-D. Model ini terdiri dari empat tahap pengembangan, yaitu define, design, develop, dan disseminate atau diadaptasikan menjadi model 4-P, yaitu pendefenisian, perancangan, pengembangan, dan penyebaran.

Instrumen penelitian yang digunakan adalah lembar validasi perangkat pembelajaran, lembar observasi keterlaksanaan LKPD, lembar observasi kemampuan guru mengelola pembelajaran, lembar observasi aktivitas peserta didik, lembar observasi aktivitas guru, angket respon peserta didik, angket respon guru, tes hasil belajar, tes motivasi belajar kimia,

Teknik analisis data pada pengembangan perangkat pembelajaran ini, digunakan teknik analisis statistik deskriptif. Data yang dianalisis adalah: Analisis data kevalidan LKPD, analisis data kepraktisan LKPD, analisis data keefektifan LKPD.

\section{HASIL PENELITIAN DAN \\ PEMBAHASAN}

1. Hasil Penelitian

a. Deskripsi hasil Tahap Pengembangan (Develop)
1. Analisis Hasil Validasi Ahli Terhadap Perangkat Pembelajaran dan Instrumen Penelitian

a) Hasil Validasi Ahli Terhadap Perangkat Pembelajaran

Adapun perangkat pembelajaran yang telah divalidasi dapat dideskripsikan sebagai berikut:

1) Lembar Kerja Peserta Didik (LKPD)

Dalam menyusun Lembar Kerja Peserta Didik (LKPD), beberapa aspek yang perlu diperhatikan dalam memvalidasi perangkat yaitu: aktivitas, materi yang disajikan, bahasa, dan waktu LKPD. Hasil validasi dari ahli dapat dirangkum pada pada Tabel 1.

Tabel 1 Rangkuman Hasil Validasi LKPD

\begin{tabular}{clcc}
\hline No & Aspek penilaian & $\bar{x}$ & Ket \\
\hline & Aktivitas & 3,60 & Sangat \\
1 & Valid \\
2 & Materi yang & 3,71 & Sangat \\
& disajikan & & Valid \\
3 & Bahasa & 3,36 & Valid \\
4 & Waktu & 3,50 & Sangat \\
& & & Valid \\
\hline & Rata-rata total & 3,54 & Sangat \\
& & & Valid \\
\hline & Percentage of & 1,00 & Reliabel \\
& Agreement & & \\
\hline
\end{tabular}

Berdasarkan Tabel 1 menunjukkan bahwa nilai rata-rata kevalidan berada pada kategori valid yaitu berada pada $(3,5 \leq \bar{x}<$ 4,0) dan berdasarkan perhitungan didapatkan koefisien reliabilitas $100 \%$ atau 1,00 . Penilaian secara umum oleh para ahli untuk LKPD adalah baik dan dapat digunakan dengan sedikit revisi.

\section{2) Rencana Pelaksanaan Pembelajaran}

Aspek-aspek yang diperhatikan dalam memvalidasi RPP adalah kesesuaian tujuan, materi yang disajikan, bahasa, sarana dan alat bantu pembelajaran, metode dan kegiatan pembelajaran, serta alokasi waktu yang digunakan. Hasil validasi dari ahli dapat dirangkum pada Tabel 2. 
Tabel 2 Rangkuman hasil validasi RPP

\begin{tabular}{|c|c|c|c|}
\hline No & Aspek penilaian & $\bar{x}$ & Ket \\
\hline 1 & Kesesuain tujuan & 3,00 & Valid \\
\hline 2 & Materi yang disajikan & 3,38 & Valid \\
\hline 3 & Bahasa & 3,25 & Valid \\
\hline 4 & $\begin{array}{l}\text { Sarana dan alat bantu } \\
\text { pembelajaran }\end{array}$ & 4,00 & $\begin{array}{c}\text { Sangat } \\
\text { Valid }\end{array}$ \\
\hline 5 & $\begin{array}{l}\text { Metode dan Kegiatan } \\
\text { pembelajaran }\end{array}$ & 3,58 & $\begin{array}{l}\text { Sangat } \\
\text { Valid }\end{array}$ \\
\hline 6 & Alokasi Waktu & 4,00 & $\begin{array}{c}\text { Sangat } \\
\text { Valid } \\
\end{array}$ \\
\hline \multicolumn{2}{|c|}{ Rata-rata penilaian total } & 3,44 & Valid \\
\hline \multicolumn{2}{|c|}{ Percentage of Agreemant } & 1,00 & Reliabe \\
\hline
\end{tabular}

Berdasarkan Tabel 2 menunjukkan bahwa nilai rata-rata kevalidan berada pada kategori sangat, yaitu berada pada $(2,5 \leq \bar{x}$ $<$ 3,5) dan berdasarkan perhitungan didapatkan koefisien reliabilitas $100 \%$ atau 1,00. Penilaian secara umum oleh para ahli untuk RPP adalah baik dan dapat digunakan dengan sedikit revisi.

\section{3) Buku Peserta didik}

Dalam penyusunan buku peserta didik, beberapa aspek yang perlu diperhatikan dalam memvalidasi perangkat, yaitu: Penjabaran konsep, konstruksi buku peserta didik, karakteristik subkonsep, dan manfaat buku peserta didik. Hasil validasi dari ahli dapat dirangkum pada pada Tabel 3

Tabel 3 Rangkuman Hasil Validasi Buku Peserta Didik

\begin{tabular}{cccc}
\hline No & Aspek penilaian & $\bar{x}$ & Ket \\
\hline 1 & Penjabaran & 3,33 & Valid \\
2 & Konsep & 3,44 & Valid \\
3 & Konstruksi & 3,50 & Sangat \\
4 & Karakteristik & 3,50 & Valid \\
& Subkonsep & & Sangat \\
& Manfaat buku & & Valid \\
& peserta didik & & \\
\hline & Rata-rata total & 3,44 & Valid \\
\hline Percentage of agreement & 1,00 & Reliabel \\
\hline
\end{tabular}

Berdasarkan Tabel 3 menunjukkan bahwa nilai rata-rata kevalidan berada pada kategori valid, yaitu berada pada $(2,5 \leq \bar{x}<$ 3,50) dan berdasarkan perhitungan didapatkan koefisien reliabilitas $100 \%$ atau 1,00 . Penilaian secara umum oleh para ahli untuk buku peserta didik adalah baik dan dapat digunakan dengan sedikit revisi. Adapun hasil validasi perangkat pembelajaran dapat dilihat pada Gambar 1

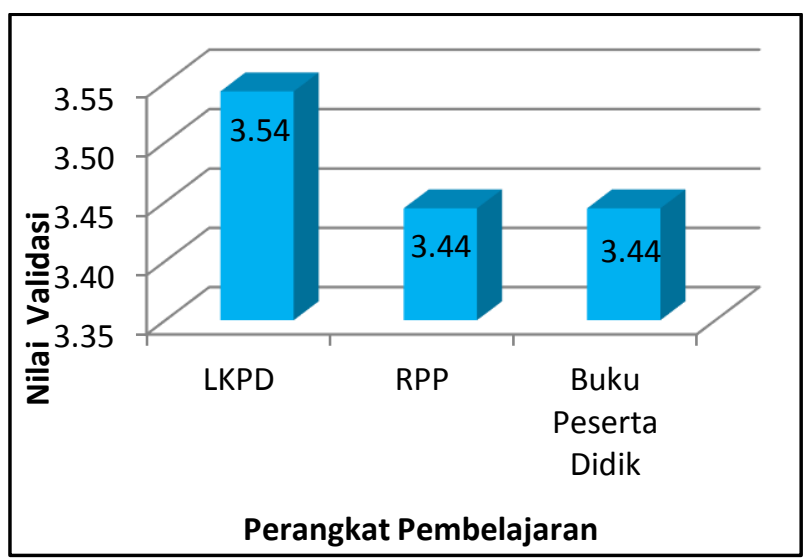

1) Hasil Validasi Ahli untuk Instrumen Penelitian

Rangkuman hasil validasi lembar instrumen ini dapat dilihat pada Tabel 4.5.

Tabel 4. Rekapitulasi Hasil Validasi terhadap Instrumen Penelitian

\begin{tabular}{|c|c|c|c|c|}
\hline No & $\begin{array}{l}\text { Instrumen } \\
\text { Penelitian }\end{array}$ & $\bar{x}$ & Keterangan & $\mathrm{R}$ \\
\hline 1. & $\begin{array}{l}\text { Lembar } \\
\text { pengamatan } \\
\text { keterlaksanaa } \\
\mathrm{n} \text { perangkat } \\
\text { pembelajaran }\end{array}$ & 3,72 & $\begin{array}{c}\text { Sangat } \\
\text { Valid }\end{array}$ & 1,00 \\
\hline 2. & $\begin{array}{l}\text { Lembar } \\
\text { respon guru } \\
\text { terhadap } \\
\text { pembelajaran }\end{array}$ & 3,56 & $\begin{array}{c}\text { Sangat } \\
\text { Valid }\end{array}$ & 1,00 \\
\hline 3. & $\begin{array}{l}\text { Lembar } \\
\text { pengamatan } \\
\text { kemampuan } \\
\text { guru } \\
\text { mengelola } \\
\text { pembelajaran }\end{array}$ & 3,57 & $\begin{array}{c}\text { Sangat } \\
\text { Valid }\end{array}$ & 1,00 \\
\hline 4. & $\begin{array}{l}\text { Lembar } \\
\text { pengamatan } \\
\text { aktivitas } \\
\text { peserta didik }\end{array}$ & 3,56 & $\begin{array}{c}\text { Sangat } \\
\text { Valid }\end{array}$ & 1,00 \\
\hline
\end{tabular}




Lembar
$\begin{aligned} & \text { respon } \\ & \text { peserta didik }\end{aligned}$
terhadap
pembelajaran

Gambar 2 Diagram batang hasil validasi insrumen penelitian

\section{Analisis Hasil Pengamatan Uji Coba lapangan}

Ujicoba dilaksanakan selama 2 kali pertemuan di mulai tanggal 4 April 2016 sampai dengan 28 Mei 2016.

\section{a. Analisis Data Kepraktisan \\ 1. Hasil Pengamatan Keterlaksanaan Perangkat Pembelajaran}

Berdasarkan hasil analisis data observasi pengamat tentang keterlaksanaan perangkat pembelajaran dari 2 kali pertemuan dapat dirangkum seperti pada Tabel 5.

Tabel 5 Hasil Pengamatan Keterlaksanaan Perangkat Pembelajaran

\begin{tabular}{clccc}
\hline No & $\begin{array}{c}\text { Aspek } \\
\text { Yang } \\
\text { Diamati }\end{array}$ & $\begin{array}{c}\text { Rata- } \\
\text { rata }\end{array}$ & $\mathrm{R}(\%)$ & Keterangan \\
\hline 1 & Sintaks & 3.92 & 1,00 & $\begin{array}{c}\text { Terlaksana } \\
\text { Seluruhnya }\end{array}$ \\
\hline 2 & $\begin{array}{l}\text { Interaksi } \\
\text { sosial }\end{array}$ & 3.70 & 1,00 & $\begin{array}{c}\text { Terlaksana } \\
\text { Seluruhnya }\end{array}$ \\
\hline 3 & $\begin{array}{l}\text { Prinsip } \\
\text { reaksi }\end{array}$ & 3.59 & 1,00 & $\begin{array}{c}\text { Terlaksana } \\
\text { Seluruhnya }\end{array}$ \\
\hline 4 & $\begin{array}{l}\text { Sistem } \\
\text { pendukung }\end{array}$ & 3.80 & 1,00 & $\begin{array}{c}\text { Terlaksana } \\
\text { Seluruhnya }\end{array}$ \\
\hline & $\begin{array}{c}\text { Rata-rata } \\
\text { Total (x) }\end{array}$ & 3.75 & 1,00 & $\begin{array}{c}\text { Terlaksana } \\
\text { Seluruhnya }\end{array}$ \\
\hline
\end{tabular}

Hasil analisis data observasi pengamat tentang keterlaksanaan perangkat pembelajaran dari hasil uji coba dapat dirangkum seperti pada gambar 3 .

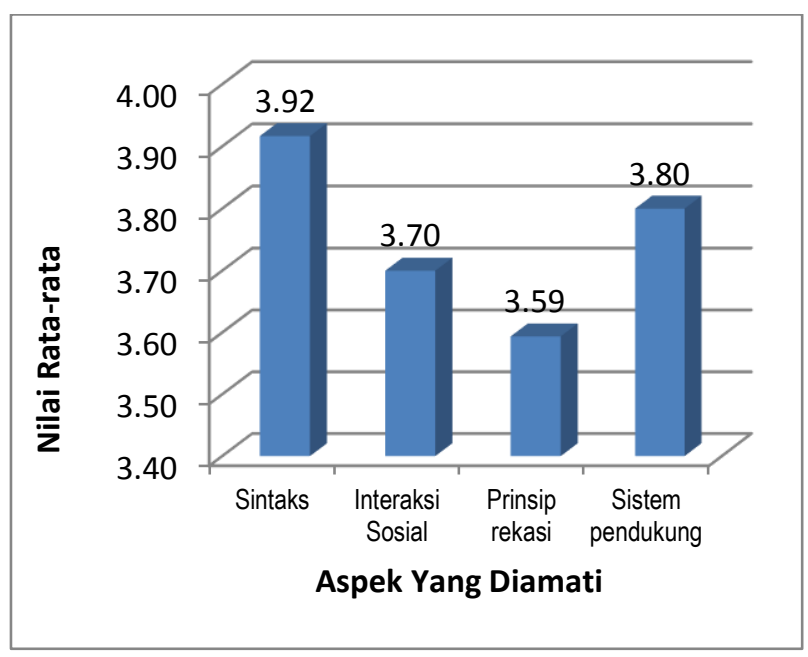

Gambar 3. Diagram pengamatan keterlaksanaan perangkat pembelajaran

Pada tabel di atas menunjukkan bahwa keterlaksanaan perangkat pembelajaran adalah berada pada nilai rata-rata $X=3.78$, yang berarti aspek dan kriteria yang diamati pada keterlaksanaan pembelajaran pada umumnya terlaksana seluruhnya $(3.5 \leq \mathrm{M}$ $\geq 4.0$ ).

2. Deskripsi Hasil Analisis Respon Guru terhadap Pembelajaran Berbasis lingkungan 
Tujuan utama analisis data respons guru terhadap proses pembelajaran adalah untuk melihat bagaimana respon guru terhadap proses pembelajaran berbasis lingkungan. Hasil analisis tersebut ditunjukkan pada Tabel 6 .

Tabel 6. Hasil Respon Guru terhadap Pembelajaran berbasis lingkungan

\begin{tabular}{clcc}
\hline No & \multicolumn{1}{c}{ Aspek } & $\begin{array}{c}\text { Rata- } \\
\text { rata } \\
\text { Persen } \\
\text { tase }\end{array}$ & $\begin{array}{c}\text { Ketera } \\
\text { ngan }\end{array}$ \\
\hline & $\begin{array}{l}\text { Penilaian terhadap } \\
\text { perangkat } \\
\text { pembelajaran dan } \\
\text { instrumen penilaian } \\
\text { hasil belajar }\end{array}$ & 90.63 & $\begin{array}{l}\text { Sangat } \\
\text { Positif }\end{array}$ \\
\hline & $\begin{array}{l}\text { Dukungan } \\
\text { perangkat } \\
\text { pembelajaran pada } \\
\text { pelaksanaan tugas } \\
\text { mengajar di kelas }\end{array}$ & 95.31 & Sangat \\
\hline 3 & $\begin{array}{l}\text { Pertanyaan/Pernyat } \\
\text { aan proses } \\
\text { pembelajaran }\end{array}$ & 94.20 & Sangat \\
\hline
\end{tabular}

Hasil analisis diatas dapat ditunjukkan pada diagram dibawah ini.

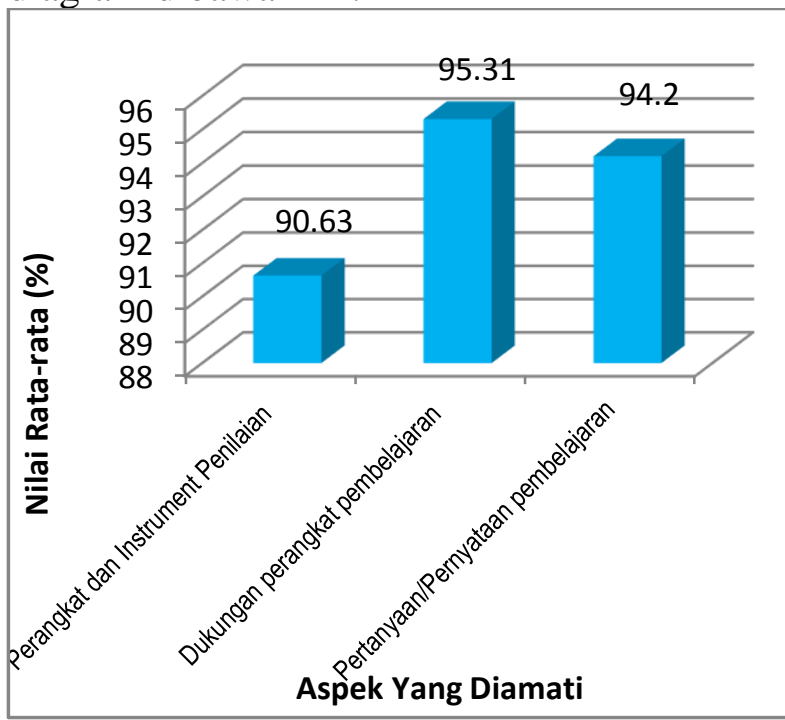

Gambar 4. Diagram persentase respon Guru Terhadap Pembelajaran

Pada Gambar 4 terlihat bahwa diagram persentase rata-rata respon guru terhadap pembelajaran yang menggunakan perangkat pembelajaran berbasis lingkungan secara keseluruhan berada dalam kategori sangat baik atau sangat positif. Dengan demikian dapat disimpulkan bahwa keterlaksanaan perangkat pembelajaran berbasis lingkungan dan respon guru yang telah diujicoba memenuhi kriteria praktis.

\section{b. Analisis Keefektifan}

Deskripsi hasil pengamatan dan analisis terhadap kriteria keefektipan sebagai berikut :

\section{Deskprisi Hasil Pengamatan Kemampuan Guru Mengelola Pembelajaran}

Berdasarkan hasil analisis data observasi pengamat tentang pengelolaan pembelajaran selama 2 kali pertemuan dapat dirangkum seperti pada tabel 7 .

Tabel 7. Hasil Pengamatan Kemampuan Guru Mengelola Pembelajaran

\begin{tabular}{llcc}
\hline No & Aspek yang diamati & $\begin{array}{c}\text { rata- } \\
\text { rata }\end{array}$ & $\begin{array}{c}\text { Keteranga } \\
\mathrm{n}\end{array}$ \\
\hline 1 & Pendahuluan & 3.83 & Tinggi \\
\hline 2 & Kegiatan inti & 3.75 & Tinggi \\
\hline 3 & Penutup & 3.75 & Tinggi \\
\hline 4 & Waktu & 4.00 & $\begin{array}{l}\text { Sangat } \\
\text { Tinggi }\end{array}$ \\
\hline 5 & $\begin{array}{l}\text { Pengamatan Suasana } \\
\text { kelas }\end{array}$ & 4.38 & $\begin{array}{l}\text { Sangat } \\
\text { Tinggi }\end{array}$ \\
\hline & Rata-rata Total (x) & 3.94 & Tinggi \\
\hline & Hasil analisis & data & observasi
\end{tabular}

kemampuan guru mengelola pembelajaran dapat dirangkum seperti pada gambar 5 .

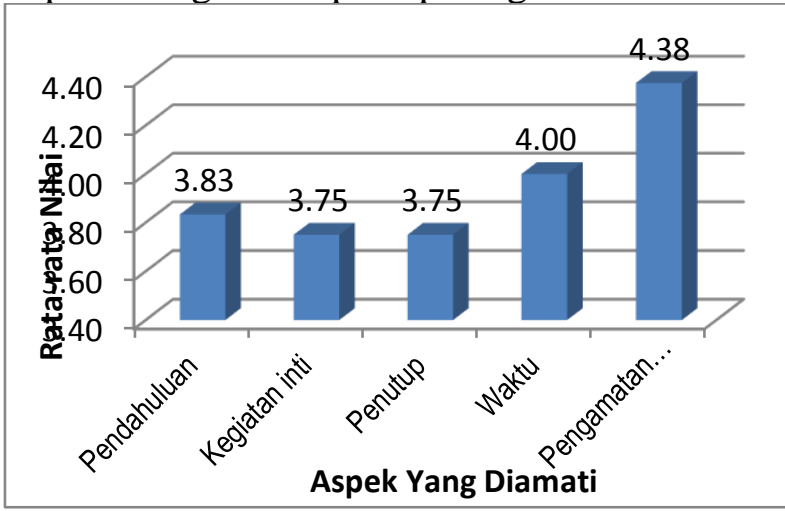

Gambar 5. Diagram kemampuan guru mengelola pembelajaran

\section{Deskripsi Hasil Pengamatan Aktivitas Peserta didik}


Adapun persentase rata-rata aktivitas peserta didik selama proses pembelajaran 2 kali pertemuan ditunjukan pada Tabel 8 .

Tabel 8 Hasil Pengamatan Aktifitas Peserta didik

\begin{tabular}{|c|c|c|c|c|c|}
\hline \multirow[t]{2}{*}{ No } & \multirow{2}{*}{$\begin{array}{c}\text { Aktifitas } \\
\text { Peserta didik }\end{array}$} & \multicolumn{3}{|c|}{$\begin{array}{c}\text { Nilai Pertemuan } \\
(\%)\end{array}$} & \multirow{2}{*}{-Kategor } \\
\hline & & I & II & Rata2 & \\
\hline 1 & $\begin{array}{l}\text { Aktif dalam } \\
\text { memperhatik } \\
\text { an penjelasan } \\
\text { guru. }\end{array}$ & 80 & 90 & 85 & $\begin{array}{l}\text { Sangat } \\
\text { Baik }\end{array}$ \\
\hline 2 & $\begin{array}{l}\text { Aktif bekerja } \\
\text { sama dalam } \\
\text { kelompok. }\end{array}$ & 88 & 94 & 91 & $\begin{array}{c}\text { Sangat } \\
\text { Baik }\end{array}$ \\
\hline 3 & $\begin{array}{l}\text { Aktif diskusi } \\
\text { kelompok/ke } \\
\text { las. }\end{array}$ & 70 & 80 & 75 & Baik \\
\hline 4 & $\begin{array}{l}\text { Aktif } \\
\text { mengajukan } \\
\text { pertanyaan } \\
\text { kepada } \\
\text { teman/guru. }\end{array}$ & 62 & 90 & 76 & Baik \\
\hline 5 & $\begin{array}{l}\text { Menjawab/m } \\
\text { enanggapi } \\
\text { pertanyaan } \\
\text { teman/guru. }\end{array}$ & 70 & 92 & 81 & $\begin{array}{c}\text { Sangat } \\
\text { Baik }\end{array}$ \\
\hline 6 & $\begin{array}{l}\text { Aktif } \\
\text { memberi } \\
\text { penjelasan } \\
\text { pada teman } \\
\text { yang } \\
\text { membutuhka } \\
\text { n. }\end{array}$ & 68 & 88 & 78 & Baik \\
\hline 7 & $\begin{array}{l}\text { Meminta } \\
\text { bimbingan } \\
\text { kepada guru } \\
\text { jika } \\
\text { mengalami } \\
\text { kesulitan di } \\
\text { dalam } \\
\text { kelompok. }\end{array}$ & 74 & 80 & 77 & Baik \\
\hline 8 & $\begin{array}{l}\text { Membuat } \\
\text { rangkuman } \\
\text { atau } \\
\text { kesimpulan. }\end{array}$ & 74 & 88 & 81 & $\begin{array}{c}\text { Sangat } \\
\text { Baik }\end{array}$ \\
\hline 9 & $\begin{array}{l}\text { Melakukan } \\
\text { kegiatan lain } \\
\text { di luar tugas } \\
\text { belajar }\end{array}$ & 30 & 16 & 23 & Baik \\
\hline
\end{tabular}

Hasil Rekapitulasi Aktivitas Peserta
Didik seperti pada Gambar 6

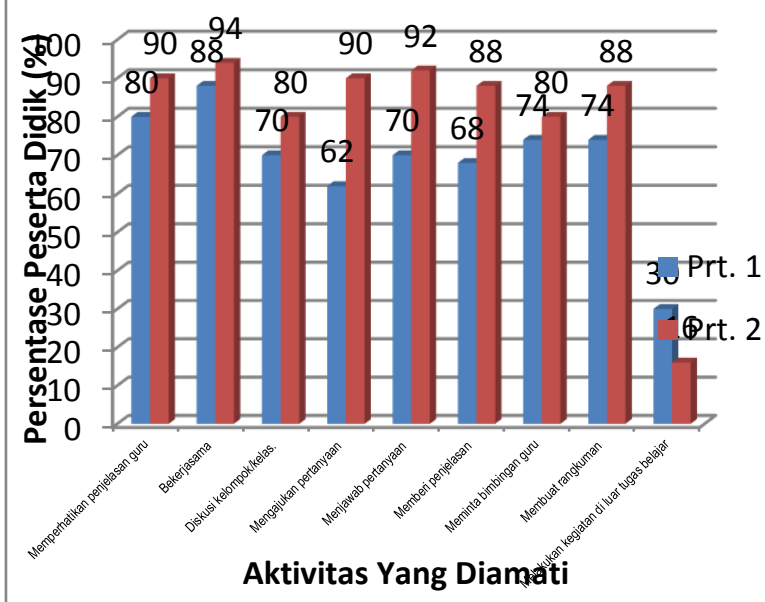

Gambar 6 Diagram hasil Analisis Aktivitas Peserta Didik

Pada diagram batang menunjukkan bahwa rata-rata persentase yang didapatkan dari setiap aspek yang diamati berada pada kategori baik dan sangat baik.

Secara umum dapat dikemukakan bahwa semua aspek yang diamati memiliki frekuensi dan persentase yang tinggi, ini berarti aktifitas peserta didik sesuai yang diharapkan karena berada pada baik dan kategori sangat baik, karena persentase yang didapatkan dari pertemuan pertama sampai pertemuan kedua rata-rata persentasenya mencapai 80,50 \% kategori baik.

\section{Deskripsi Hasil Analisis Respon} Peserta didik terhadap Pembelajaran Berbasis lingkungan

Tujuan utama analisis data respons peserta didik terhadap proses pembelajaran adalah untuk melihat bagaimana respon peserta didik terhadap proses pembelajaran berbasis lingkungan. Hasil analisis tersebut ditunjukkan pada Tabel 9.

Tabel 9 Hasil Respon peserta didik terhadap Pembelajaran berbasis lingkungan

\begin{tabular}{clcc}
\hline No & Aspek yang diamati & $\begin{array}{c}\text { Rata- } \\
\text { rata } \\
\text { Persen } \\
\text { tase }\end{array}$ & $\begin{array}{c}\text { Ketera } \\
\text { ngan }\end{array}$ \\
\hline 1 & $\begin{array}{l}\text { Perangkat pembelajaran } \\
\text { dan Proses Pembelajaran }\end{array}$ & 91.88 & $\begin{array}{c}\text { Sangat } \\
\text { Positif }\end{array}$ \\
\hline 2 & Buku Peserta didik & 90.97 & $\begin{array}{c}\text { Sangat } \\
\text { Positif }\end{array}$ \\
\hline 3 & LKPD & 93.49 & $\begin{array}{c}\text { Sangat } \\
\text { Positif }\end{array}$ \\
\hline & Rata-rata total \% & 92.11 & SP \\
\hline
\end{tabular}


Hasil analisis di atas dapat ditunjukkan pada Gambar 7.

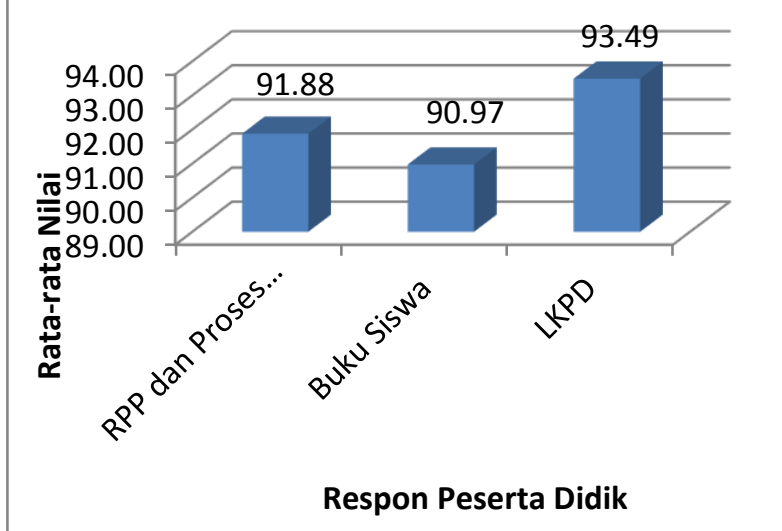

Gambar 7. Diagram persentase respon Peserta didik Terhadap Pembelajaran

Pada Gambar 4.7 terlihat bahwa diagram persentase rata-rata respon peserta didik terhadap pembelajaran yang menggunakan perangkat pembelajaran berbasis lingkungan secara keseluruhan berada dalam kategori sangat baik atau sangat positif.

\section{Deskripsi Hasil Analisis Tes Hasil Belajar}

Tes hasil belajar yang digunakan pada penelitian ini ialah tes pilihan ganda sebanyak 30 nomor. Analisis tes digunakan untuk mengetahui tingkat pencapaian hasil belajar. Rekapitulasi skor yang didapatkan peserta didik dapat dirangkum pada Tabel 10.

Tabel 10. Rekapitulasi Skor Tes Hasil Belajar Peserta Didik

\begin{tabular}{lc}
\hline \multicolumn{1}{c}{ Variabel } & $\begin{array}{c}\text { Nilai } \\
\text { Statistic }\end{array}$ \\
\hline Subjek Penelitian & 25 \\
\hline Skor Ideal & 100 \\
\hline Rata-rata Nilai & 81.47 \\
\hline Nilai Tertinggi & 90.00 \\
\hline Nilai Terendah & 63.33 \\
\hline Rentang Nilai & 26.67 \\
\hline Jumlah Peserta didik Yang Tuntas & 22 \\
\hline Jumlah Peserta didik Yang Tidak & 3 \\
\hline Tuntas & 88.00 \\
\hline
\end{tabular}

Jika skor hasil belajar dikelompokkan dalam lima kategori ketuntasan, maka diperoleh tabel distribusi frekuensi seperti pada tabel 11 .

Tabel 11. Distribusi Frekuensi dan Persentase skor hasil belajar

\begin{tabular}{|c|c|c|c|c|}
\hline No & Nilai & Kategori & Frekuensi & $\begin{array}{l}\text { Perse } \\
\text { ntase }\end{array}$ \\
\hline 1 & $85-100$ & $\begin{array}{l}\text { Sangat } \\
\text { Tinggi }\end{array}$ & 7 & 28.00 \\
\hline 2 & $65-84$ & Tinggi & 17 & 68.00 \\
\hline 3 & $55-64$ & Sedang & 1 & 4.00 \\
\hline 4 & $35-54$ & Rendah & 0 & 0.00 \\
\hline 5 & $0-34$ & $\begin{array}{l}\text { Sangat } \\
\text { Rendah }\end{array}$ & 0 & 0.00 \\
\hline
\end{tabular}

Hasil distribusi frekuensi dan persentase skor hasil belajar dapat digambarkan pada diagram berikut ini.

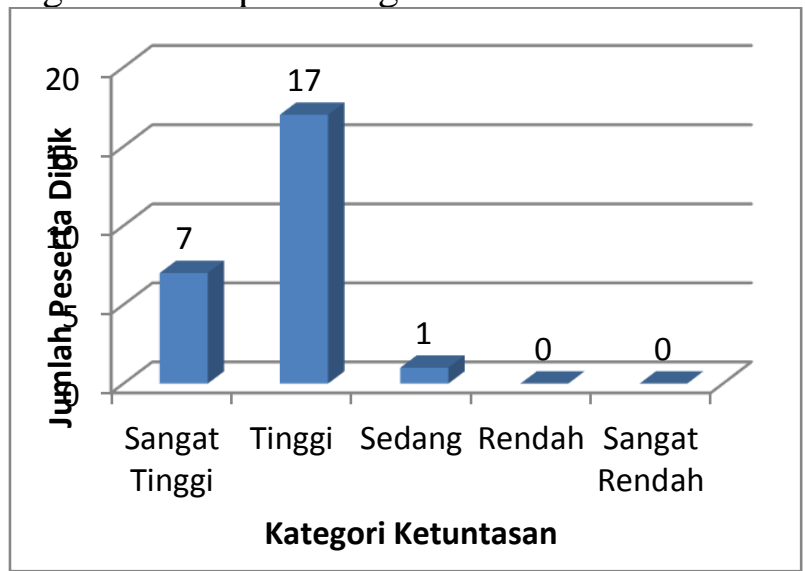

Gambar 8. Diagram Hasil analisis Skor Tes Hasil Belajar Peserta Didik

Berdasarkan diagram di atas menunjukkan bahwa persentase rata-rata pencapaian hasil belajar peserta didik berada pada kategori tinggi.

\section{Deskripsi Hasil Analisis Motivasi Belajar Kimia}

Untuk mengetahui motivasi belajar kimia yang digunakan pada penelitian ini ialah angket motivasi belajar sebanyak 30 nomor. Analisis motivasi belajar digunakan untuk mengetahui tanggapan peserta didik terhadap mata pelajaran kimia setelah mengikuti proses belajar berbasis lingkungan. Rekapitulasi skor rata yang didapatkan peserta didik tiap aspek dapat dirangkum pada Tabel 12. 
Tabel 12. Rekapitulasi nilai rata skor motivasi belajar peserta didik

\begin{tabular}{|c|c|c|}
\hline No. & Aspek yang diamati & Rata-rata (\%) \\
\hline 1 & $\begin{array}{ll}\text { Kesiapan } & \text { memulai } \\
\text { pelajaran } & \end{array}$ & 77.33 \\
\hline 2 & $\begin{array}{l}\text { Keyakinan menguasai } \\
\text { materi }\end{array}$ & 78.40 \\
\hline 3 & Kemauan belajar mandiri & 64.80 \\
\hline 4 & $\begin{array}{l}\text { Kemauan bertanya materi } \\
\text { pelajaran }\end{array}$ & 69.20 \\
\hline 5 & Tangapan terhadap guru & 85.60 \\
\hline 6 & $\begin{array}{l}\text { Disiplin mengerjakan } \\
\text { tugas }\end{array}$ & 73.87 \\
\hline 7 & $\begin{array}{ll}\text { Tanggapan } & \text { terhadap } \\
\text { pelajaran lain } & \end{array}$ & 98.40 \\
\hline 8 & $\begin{array}{l}\text { Pengulangan materi yang } \\
\text { diajarkan }\end{array}$ & 79.20 \\
\hline 9 & $\begin{array}{l}\text { Disiplin dalam belajar } \\
\text { kimia }\end{array}$ & 75.20 \\
\hline & Nilai rata-rata & 78.00 \\
\hline
\end{tabular}

Hasil rekapitulasi motivasi belajar dapat digambarkan pada diagram berikut ini.

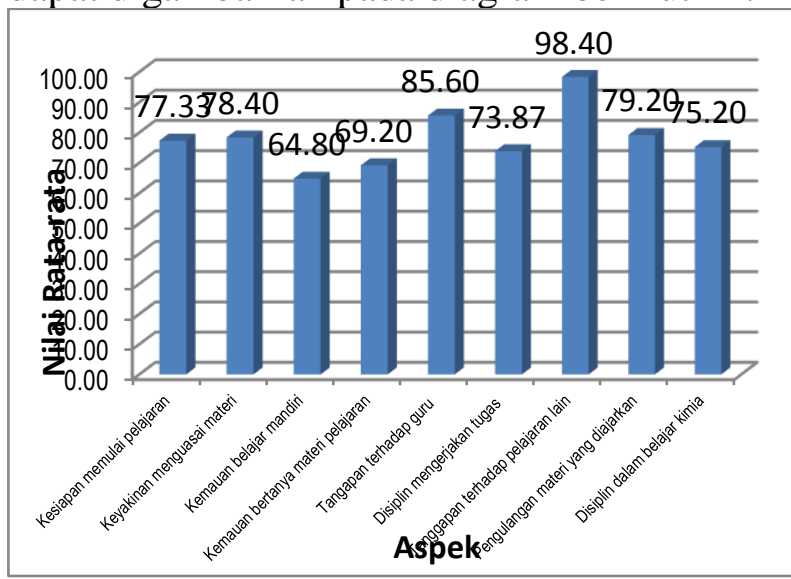

Gambar 9 Diagram hasil analisis motivasi belajar peserta didik

Berdasarkan diagram di atas menunjukkan bahwa persentase rata-rata pencapaian hasil belajar peserta didik berada pada kategori sangat baik.

\section{Pembahasan Hasil Penelitian}

\section{a. Nilai Kevalidan Perangkat Pembelajaran}

Berdasarkan hasil pengembangan dan penelitian yang telah dilakukan, maka diperoleh kevalidan perangkat pembelajaran yang dimaksud adalah RPP, BPD, LKPD dan THB.

\section{Lembar Kerja Peserta Didik (LKPD)}

Hasil analisis kevalidan lembar kerja peserta didik (LKPD) pada tabel 3, dapat dijelaskan bahwa nilai rata-rata kevalidan untuk aspek bahasa $(V=3,36)$ termasuk dalam kategori "Valid" $(2,50 \leq V<3,50)$, sedangkan aspek aktivitas $V=3,60$ ), aspek materi yang disajikan $(V=3,71)$ dan aspek waktu $(V=3,50)$ termasuk dalam kategori "Sangat Valid" $(3,50 \leq V \leq 4,00)$. Nilai ratarata total kevalidan LKPD yang diperoleh adalah 3,54 termasuk dalam kategori "Sangat Valid" (3,50 $\leq V \leq 4,00)$, jadi ditinjau dari keseluruhan aspek penilaian, LKPD ini dinyatakan memenuhi kriteria kevalidan dan dinyatakan reliabel.

\section{Rencana Pelaksanaan Pembelajaran (RPP)}

Hasil penelitian terhadap pengembangan RPP pada tabel 1 dapat dijelaskan bahwa nilai rata-rata kevalidan untuk aspek kesesuain tujuan $(V=3,00)$, aspek materi yang disajikan $(V=3,38)$, dan aspek bahasa $(V=3,25)$ termasuk dalam kategori "Valid" $(2,50 \leq V<3,50)$, sedangkan nilai rata-rata kevalidan untuk aspek sarana dan alat bantu pembelajaran ( $V$ $=4,00)$, aspek metode dan kegiatan pembelajaran $(V=3,58)$, dan aspek alokasi waktu $(V=4,00)$ termasuk dalam kategori "Sangat Valid" $(3,50 \leq V \leq 4,00)$. Nilai ratarata total kevalidan RPP yang diperoleh adalah 3,44 termasuk dalam kategori "Valid" $(2,50 \leq V<3,50)$, jadi ditinjau dari keseluruhan aspek penilaian, RPP ini dinyatakan memenuhi kriteria kevalidan dan dinyatakan reliabel.

\section{Buku Peserta Didik (BPD)}

Hasil analisis kevalidan buku peserta didik (BPD) pada tabel 2, dapat dijelaskan bahwa nilai rata-rata kevalidan untuk aspek penjabaran konsep $(V=3,33)$ dan aspek konstruksi $(V=3,44)$ termasuk dalam kategori "Valid" $(2,50 \leq V<3,50)$, sedangkan aspek karakteristik subkonsep ( $V$ $=3,50$ ) dan aspek manfaat buku peserta didik $(V=3,50)$ termasuk dalam kategori 
"Sangat Valid" $(3,50 \leq V \leq 4,00)$. Nilai ratarata total kevalidan BPD yang diperoleh adalah 3,44 termasuk dalam kategori "Valid" $(2,50 \leq V<3,50)$, jadi ditinjau dari keseluruhan aspek penilaian, BPD ini dinyatakan memenuhi kriteria kevalidan dan dinyatakan reliabel.

\section{b. Nilai Kepraktisan Perangkat Pembelajaran}

Data hasil penerapan perangkat pembelajaran diperoleh dari hasil pengamatan oleh dua orang pengamat yang telah ditunjuk untuk menilai sejauhmana perangkat-perangkat tersebut dapat dilaksanakan dan respon guru terhadap penggunaan LKP dalam pembelajaran.

1. Keterlaksanaan Perangkat Pembelajaran

Dari hasil pengamatan observer keterlaksanaan perangkat pembelajaran berada dalam kategori terlaksana seluruhnya dengan tingkat reliabilitas tinggi. Hal ini berarti bahwa perangkat yang telah dikembangkan dapat digunakan dalam pembelajaran berorientasi metode pembelajaran berbasis lingkungan khususnya pada materi pemisahan campuran dan analisis. Tingkat keterlaksanaan perangkat tersebut menjadi dasar bahwa perangkat yang dikembangkan mampu dilaksanakan oleh guru dengan baik.

2. Respon Guru

Respon yang diberikan oleh guru terhadap perangkat pembelajaran dalam hal imi RPP, BPD dan LKPD pada umumnya sangat positif. Keberadaan perangkatperangkat pembelajaran tersebut dirasakan sangat membantu dalam proses pembelajaran, khususnya pembelajaran pada materi pemisahan dan analisis. Selain pembelajaran yang terstruktur, proses pembelajaran yang dilakukan melalui perangkat pembelajaran tersebut dinilai dapat lebih terarah dan waktu yang dapat kendalikan.

Secara umum gambaran respon guru dalam pembelajaran berbasis lingkungan adalah berada dalam kategori sangat baik atau sangat positif. Hal ini menunjukkan bahwa pembelajaran berbasis lingkungan model kooperatif tipe STAD beserta perangkatnya direspon sangat baik dan diterima oleh pengamat (guru).

\section{c. Nilai Keefektifan Perangkat Pembelajaran}

Perangkat pembelajaran dikatakan efektif apabila memenuhi 3 dari 4 kriteria keefektifan dengan syarat kriteria 1 harus dipenuhi. Kriteria-kriteria tersebut, yaitu: (1) ketercapaian hasil belajar yaitu $80 \%$ peserta didik mencapai penguasaan bahan ajar minimal 75 (mencapai KKM 75), (2) aktivitas peserta didik dan guru selama kegiatan belajar memenuhi kriteria toleransi waktu yang telah ditetapkan, (3) lebih dari $50 \%$ peserta didik memberikan respon positif terhadap penerapan model pembelajaran kooperatif tipe $S T A D$, dan (4) kemampuan guru mengelola pembelajaran dengan menggunakan perangkat pembelajaran kooperatif tipe $S T A D$ berada dalam kategori minimal tinggi $(3 \leq \mathrm{KG}<4)$.

1. Kemampuan guru dalam mengelola pembelajaran

Kemampuan guru dalam mengelola pembelajaran dikatakan memadai jika guru dalam mengelola pembelajaran berada minimal dalam kategori "tinggi". Berdasarkan hasil analisis kemampuan guru dalam mengelola pembelajaran yang ditunjukkan pada tabel 7 dapat dijelaskan bahwa nilai rata-rata untuk kegiatan pendahuluan adalah $\overline{K G}=3,83$, kegiatan inti adalah $\overline{K G}=3,75$, dan penutup adalah $\overline{K G}=$ 3,75 termasuk dalam kategori tinggi $(3 \leq$ $\mathrm{KG}<4)$. Sedangkan untuk kegiatan dalam pengelolaan waktu adalah $\overline{K G}=4,00$, dan kegiatan pengamatan suasana kelas adalah $\overline{K G}=4,38$ termasuk dalam kategori sangat tinggi $(4 \leq \mathrm{KG} \leq 5)$. Nilai rata-rata total pengelolaan pembelajaran diperoleh adalah $\overline{K G}=3,94$ nilai tersebut termasuk dalam kategori tinggi $(3 \leq \mathrm{KG}<4)$. Jadi ditinjau dari keseluruhan aspek, kemampuan guru dalam mengelola pembelajaran kimia berbasis lingkungan dengan model kooperatif terlaksana dengan baik.

2. Aktivitas peserta didik 
Selama berlangsungnya pembelajaran berorientasi metode pembelajaran berbasis lingkungan dengan materi pemisahan dan analisis dilakukan pengamatan dan penilaian terhadap aktivitas peserta didik dalam proses pembelajaran.

Persentase rata-rata aktivitas peserta didik dalam proses pembelajaran diperoleh sebesar $80,5 \%$, nilai tersebut termasuk dalam kategori baik. Jadi ditinjau dari keseluruhan aktivitas peserta didik dalam pembelajaran kimia berbasis lingkungan dengan model kooperatif tipe STAD terlaksana dengan baik.

3. Respon Peserta Didik

Secara umum gambaran respon peserta didik dalam pembelajaran berorientasi metode pembelajaran berbasis lingkungan sebesar $92.11 \%$ berada dalam kategori sangat baik atau sangat positif. Artinya proses pembelajaran berorientasi metode pembelajaran berbasis lingkungan beserta perangkat yang digunakan dapat diterima oleh peserta didik.

a) Respon peserta didik tentang RPP dan proses pembelajaran

Sebagian besar peserta didik $(91,88 \%)$ sangat senang dengan perangkat pembelajaran dan proses pembelajaran kimia berbasis lingkungan pada materi pemisahan campuran dan analisis karena materi yang diberikan berkaitan dengan masalah dalam kehidupan sehari-hari. Peserta didik merasa bahwa materinya mudah dipamahi. Beberapa peserta didik juga mengatakan bahwa materi pelajaran kimia kadang susah dan kadang mudah.

b) Respon peserta didik tentang buku peserta didik (BPD)

Pada umumnya peserta didik (90.97\%) sangat senang dengan buku peserta didik yang disusun, karena memberikan panduan materi yang akan dipelajari dan konsep yang hendak dipahami. Buku peserta didik yang selama ini digunakan oleh peserta didik sudah berbentuk instant tanpa mempertibangkan tingkat keterbacaan dan kemampuan peserta didik sehingga peserta didik mengalami kesulitan dalam memahami materi yang disajikan. c) Respon peserta didik tentang lembar kerja peserta didik (LKPD)

Secara umum peserta didik 93.49\% memberikan respon yang sangat positif terhadap LKPD yang dikembangkan. LKPD yang dikembangkan memungkinkan peserta didik bertukar pikiran dengan peserta didik lain ataupun dengan guru pembimbing, sehinggga peserta didik menganggap LKPD yang dikembangkan sangat membantu dalam memahami konsep yang diajarkan. Berbeda dengan LKPD yang selama ini digunakan, cenderung mengarahkan peserta didik untuk bekerja secara individu dan bahkan hanya menjadi beban materi yang harus dikuasai oleh peserta didik. Tidak ada secara khusus dalam LKPD yang digunakan selama ini memberikan proporsi waktu atau petunjuk yang memadai bagi peserta didik untuk bekerja secara berkelompok atau berdiskusi dengan peserta didik lain atau dengan gurunya. Hasil lain dari pelaksanaan uji coba adalah sangat sedikit waktu yang digunakan oleh peserta didik untuk melakukan aktivitas yang tidak memiliki relevansi dengan pelaksanaan pembelajaran 4. Tes Hasil Belajar

Berdasarkan data yang diperoleh dan telah dianalisis dapat dilihat pada tabel 11 menunjukkan bahwa hasil belajar peserta didik kelas XII Keperawatan A SMK Negeri 3 Bantaeng terhadap pelajaran kimia pada materi pemisahan campuran dan analisis diperoleh rata-rata nilai peserta didik sebesar 81.47 dari nilai ideal 100. Nilai terendah yang diperoleh peserta didik adalah 63.33 dan nilai tertinggi yang diperoleh peserta didik adalah 90,00 dengan rentang nilai 26.67. Adapun sebaran hasil belajar peserta didik yaitu 1 orang (4\%) dalam kategori sedang, 17 orang $(68 \%)$ dalam kategori tinggi, dan 7 orang $(28 \%)$ dalam kategori sangat tinggi.

Data tersebut di atas menunjukkan bahwa peserta didik memperoleh pemahaman yang baik terhadap materi yang disajikan dengan menggunakan perangkat pembelajaran berbasis lingkungan dengan model pembelajaran kooperatif tipe STAD. Hal ini dapat dilihat bahwa banyaknya 
peserta didik yang tuntas belajar yaitu peserta didik yang memperoleh nilai diatas nilai KKM (75) sebanyak 22 orang $(88 \%)$ dari 25 orang peserta didik. Sedangkan peserta didik yang belum tuntas, yaitu peserta didik yang memperoleh nilai $0-74$ sebanyak 3 orang (12\%) dari 25 orang peserta didik. Perkembangan kemampuan peserta didik mengalami peningkatan.

5. Motivasi Belajar

Berdasarkan data yang diperoleh dan telah dianalisis dapat dilihat pada tabel 12 menunjukkan bahwa motivasi belajar peserta didik kelas XII Keperawatan A SMK Negeri 3 Bantaeng terhadap pelajaran kimia diperoleh rata-rata nilai peserta didik sebesar $78,00 \%$ dalam kategori baik dari nilai ideal 100. Motivasi peserta didik pada aspek kesiapan memulai pelajaran kimia sebesar $77.33 \%$ dalam kategori baik, aspek keyakinan terhadap kemampuan menguasai materi kimia sebesar 78.40 dalam kategori baik, aspek kemauan belajar secara mandiri sebesar $64.80 \%$ dalam kategori baik, aspek kemauan untuk bertanya jika kurang mengerti materi pelajaran sebesar $69.20 \%$ dalam kategori baik, aspek terhadap guru yang menyampaikan materi sebesar $85.60 \%$ dalam kategori sangat baik, aspek disiplin dalam mengerjakan tugas dari guru sebesar $73.87 \%$ dalam kategori baik, aspek tanggapan terhadap mata pelajaran yang lain sebesar $98.40 \%$ dalam kategori sangat baik, aspek pengulangan lagi materi yang telah diajarkan sebesar $79.20 \%$ dalam kategori baik, aspek disiplin dalam belajar kimia sebesar $75.20 \%$ dalam kategori baik.

Berdasarkan data tersebut di atas menunjukkan bahwa peserta didik mempunyai motivasi belajar yang baik setelah mengikuti pembelajaran berbasis lingkungan dengan model pembelajaran kooperatif tipe STAD. Hal ini dapat dilihat dari rekapitulasi motivasi belajar untuk tiap peserta didik yaitu 5 orang (20\%) memupunyai motivasi belajar yang sangat baik dan 20 orang $(80 \%)$ mempunyai motivasi belajar yang baik terhadap pelajaran kimia. Motivasi belajar peserta didik mengalami peningkatan.

\section{KESIMPULAN}

Berdasarkan hasil penelitian dan pembahasan, dapat disimpulkan bahwa perangkat pembelajaran kimia berbasis lingkungan khususnya LKPD pada materi pemisahan campuran dan analisis dapat dikatakan telah memenuhi kriteria kevalidan berada pada kategori "Sangat Valid". Sedangkan kevalidan RPP dan BPD sebagai data pendukung berada pada kategori "Valid".

Perangkat pembelajaran ini dapat dikatakan praktis karena keterlaksanaan perangkat pembelajaran berada pada kategori terlaksana seluruhnya dan respon guru terhadap pembelajaran berorientasi metode pembelajaran berbasis lingkungan berada pada kategori sangat positif. Perangkat pembelajaran ini telah memenuhi kriteria keefektifan dengan hasil: (1) kemampuan guru dalam mengelola pembelajaran berada pada kategori tinggi; (2) peserta didik menjadi lebih aktif dalam proses pembelajaran, hal ini terlihat aktivitas peserta didik secara keseluruhan berada pada kategori baik; (3) respon peserta didik terhadap pembelajaran model kooperatif tipe STAD yang berbasis lingkungan berada pada kategori sangat positif; (4) hasil belajar peserta didik memiliki rata-rata nilai sebesar 81.47 dari nilai ideal 100 dengan peserta didik yang tuntas belajar sebanyak 22 orang $(88 \%)$ dari 25 orang peserta didik (5) motivasi belajar peserta didik mengalami peningkatan dengan 5 orang $(20 \%)$ peserta didik dalam kategori sangat baik dan 20 orang $(80 \%)$ peserta didik dalam kategori baik terhadap pelajaran kimia.

\section{DAFTAR PUSTAKA}

\begin{tabular}{|c|c|c|}
\hline Azhar & $\begin{array}{c}\text { Arsyad. } \\
\text { Pembelajaran. }\end{array}$ & $\begin{array}{l}\text { (2009). } \\
\text { Jakarta: }\end{array}$ \\
\hline
\end{tabular}

BSNP. 2007. Peraturan Menteri Pendidikan Nasional Republik Indonesia No. 41 Tahun 2007 tentang Standar Isi untuk Satuan Pendidikan Dasar dan Menengah. Jakarta:BSNP. 
Erawati, E.D. 2009. Kimia SMK Kelas XII Kelompok Teknologi, Kesehatan dan Pertanian. Bogor:Yudisthira.

Dimyanti. M. 2006. Belajar dan Pembelajaran. Jakarta:Depdikbud.

Hadi, \& Mulyatiningsih. (2011). Literasi Sains.http://vivitamuzaki,wordpress .com. /2011/07/09/literasi-sains/, (6 Maret 2012).

Hamalik, Oemar. (1986). Media Pendidikan. Bandung: Alumni.

Hobri. 2009. Metodologi Penelitian Pengembangan [Aplikasi Pada penelitian Pendidikan Matematika]. Jember : Pena Salsabila.

Hurhadi. 2004. Pembelajaran Kontekstual dan Penerapannya dalam KBK. Malang: UM Press.

Purwadarminta. 2009. Kamus Besar Bahasa Indonesia Edisi Kelima.

Mulyasa, E. 2006. Kurikulum Tingkat Satuan Pendidikan. Jakarta: PT. Remaja Rosdakarya.

E. 2007. Kurikulum Tingkat Satuan Pendidikan. Bandung: Rosda Karya.

Nurdin. 2007. Model Pembelajaran Matematika yang Menumbuhkan Kemampuan Metakognitif untuk Menguasai Bahan Ajar. Ringkasan Disertasi tidak diterbitkan. Surabaya: PPs UNESA.

PPs UNM. 2012. Pedoman Penulisan tesis dan Disertasi Program Pascasarjana UNM Makassar. Makassar: PPs UNM

Purwanto, N. 1992. Prinsip-prinsip dan teknik Evaluasi Pengajaran. Jember: UPT Dinas Balai Pengembangan Pendidikan.

Riduwan. 2004. Metode Riset. Jakarta: Rineka Cipta.

$\begin{array}{ccr}\text { 2007. Skala } & \text { Pengukuran } \\ \text { Variabel } & \text { Variabel } & \text { Penelitian. } \\ \text { Bandung: Alfabeta. } & \\ \text { 2009. Metode dan Teknis } \\ \text { Menyusun } & \text { Tesis. } & \text { Bandung: } \\ \text { Alfabeta } & & \end{array}$

Slavin, Robert E. 1995. Cooperative Learning Theory, Research, and Practice. USA: The Jhons Hopkins University.

Sofyan Salam, Deri Bongkona. 2012. Pedoman Penulisan Tesis dan Disertasi. Makassar:Program Pascasarjana Universitas Negeri Makassar.

Sugiyanto. 2007. Modul Pendidikan dan Latihan Profesi Guru (PLPG) Model-Model Pembelajaran Inovatif Panitia Sertifikasi Guru Rayon 13 Surakarta.

Sugiyono. 2008. Metode Penelitian Pendidikan. Bandung:Alfabeta.

Thiagarajan, S., Dorothy S. Semmel, and Semmel, dan Melvin I Semmel. 1974. Instructional Development for Training Teachers of Exceptional Children. Source Book. Bloomington: Center for Innovation on Teaching The Handicapped.

Trianto. 2007. Model Pembelajaran Terpadu dalam Teori dan Praktek. Jakarta:Prestasi Pustaka. . 2008. Mendesain Pembelajaran Kontekstual di Kelas. Surabaya : Kencana Pranada Media Group. 2009. Mendesain Model Pembelajaran Inovatif- Progresif. Surabaya : Cerdas Pustaka. 2011. Model- model Pembelajaran: Mengembangkan Profesionalisme Guru. Jakarta: Rajawali Pers.

Winarno., Djumiarti, E. 2003. Perencanaan Pembelajaran. Jakarta:Depdiknas. 